\title{
PENGARUH KONSENTRASI IBA (Indole 3 Butyric Acid) DAN TEKNIK PENYEMAIAN TERHADAP PERTUMBUHAN BIBIT MANGGIS (Garcinia mangostana L.) ASAL BIJI
}

\author{
Dewi Delliana, Nurdiati Al-Hamidy, Rugayah \& Agus Karyanto \\ Jurusan Agroteknologi, Fakultas Pertanian Universitas Lampung \\ J1. Sumantri Brojonegoro No.1 Bandar Lampung 35145 \\ Email : rugayahbw@yahoo.com
}

\begin{abstract}
ABSTRAK
Manggis (Garcinia mangostana L.) merupakan tanaman buah yang memiliki laju pertumbuhan sangat lambat karena sistem perakarannya terbatas, sehingga penyerapan air dan unsur hara rendah. Salah satu upaya untuk meningkatkan pertumbuhan akar dan tajuk adalah dengan pemberian IBA dan teknik penyemaian. Penelitian ini bertujuan untuk mengetahui : (1) konsentrasi IBA yang menghasilkan pertumbuhan terbaik bibit tanaman manggis, (2) perbedaan pengaruh antara teknik penyemaian tanam langsung dan pindah tanam pada pertumbuhan bibit tanaman manggis, dan (3) pengaruh interaksi antara konsentrasi IBA dan teknik penyemaian pada pertumbuhan bibit tanaman manggis. Penelitian ini dilakukan pada bulan Januari - Mei 2016 di rumah kaca gedung Hortikultura Universitas Lampung. Penelitian ini menggunakan rancangan acak kelompok (RAK) dengan perlakuan faktorial yang terdiri dari dua faktor $(4 \mathrm{x} 2)$. Faktor pertama: taraf konsentrasi IBA (A) yang terdiri: 0 ppm ( $\left.\mathrm{a}_{0}\right)$, 25 ppm ( $\left.a_{1}\right), 50$ ppm $\left(a_{2}\right)$, dan 75 ppm $\left(a_{3}\right)$. Faktor kedua: teknik penyemaian $(B)$ : tanam langsung $\left(b_{1}\right)$ dan pindah tanam $\left(b_{2}\right)$. Hasil penelitian menunjukkan bahwa pemberian IBA tidak berpengaruh nyata pada semua variabel pengamatan kecuali pada diameter batang akhir justru menurunkan. Teknik penyemaian dan interaksi antara kedua perlakuan tersebut juga tidak menunjukkan adanya pengaruh yang nyata pada semua variabel pengamatan.
\end{abstract}

Kata kunci: IBA, konsentrasi, manggis, dan teknik penyemaian.

\section{PENDAHULUAN}

Manggis (Garcinia mangostana L.) merupakan salah satu buah eksotik tropika yang telah dikenal di mancanegara sebagai "Queen of Fruits". Bentuk buah yang artistik dan citarasa khas serta khasiatnya menyebabkan buah ini disukai oleh konsumen walaupun hanya $30 \%$ bagian buah manggis yang dapat dimakan, sehingga manggis memiliki nilai ekonomis yang tinggi (Fanani, 2014).

Manggis merupakan buah unggulan Indonesia yang termasuk buah paling berpotensi untuk diekspor dibandingkan dengan buah-buahan lainnya seperti pisang, mangga, nanas segar, maupun pepaya. Menurut Departemen Pertanian (2015), ekspor manggis semakin meningkat setiap tahunnya dari 8.726 ton (2013) menjadi 10.081 ton (2014). Total produksi manggis pada tahun 2014 mencapai 87.154 ton, artinya hanya $11,6 \%$ buah manggis yang layak ekspor.

Menurut Salim dkk. (2010), produksi manggis yang ada sekarang ini umumnya berasal dari tanaman rakyat yang belum dibudidayakan secara intensif, sehingga produktivitas buah yang dihasilkan masih rendah. Salah salah satu sebabnya yaitu kurangnya penyediaan bibit manggis yang bermutu dikarenakan masih sangat minim sentuhan teknologi.

Di Indonesia, tanaman manggis yang ada sekarang merupakan tanaman yang telah berumur puluhan tahun. Tanaman buah ini termasuk ke dalam tanaman yang sangat lambat pertumbuhnnya. Umumnya, tanaman manggis yang diperbanyak melalui biji mulai berbuah pada umur $8-15$ tahun. Selain perbanyakan melalui biji, tanaman manggis dapat diperbanyak dengan cara vegetatif yaitu sambung pucuk atau penyusuan yang mampu berbuah pada umur 5-6 tahun (Sunarjono, 2000). Namun petani lebih menyukai bibit manggis asal biji karena memiliki sistem perakaran yang kuat dan produktivitasnya lebih lama. Untuk mempercepat pertumbuhan bibit tersebut dapat dilakukan dengan penambahan pemacu pertumbuhan akar berupa zat pengatur tumbuh salah satunya adalah IBA (Indole 3 Butyric Acid).

Pemberian IBA dapat mempengaruhi pembelahan sel dan perbanyakan tunas. Hal ini disebabkan penggunaan IBA dalam konsentrasi tertentu dapat menimbulkan pertambahan perakaran yang disebabkan oleh kandungan kimia yang dimiliki IBA lebih stabil dan daya kerjnya lebih lama (Wudianto, 2005). 
Menurut Budianto dkk. (2013), perendaman IBA pada pembibitan sirih merah (Piper crotatum Ruiz \& $P a v)$ secara stek dengan lama perendaman 3 jam memberikan pengaruh yang berkorelasi positif terhadap variabel pengamatan panjang akar, jumlah akar dan bobot kering akar. Hal ini ditunjukkan dengan penambahan panjang akar dan jumlah akar pada usia 12 MST.

Pada penelitian Shofiana dkk. (2013), menyebutkan bahwa hormon IBA memberikan pengaruh yang terbaik pada konsentrasi optimal 2000 ppm , sedangkan konsentrasi di bawah (500 dan 1000 ppm) atau di atas (4000 ppm) memberikan hasil sebaliknya pada pertumbuhan akar stek batang tanaman buah naga (Hylocereus undatus).

Menurut Yulianto dkk. (2015), pemberian IBA konsentrasi $100 \mathrm{ppm}$ pada sambung samping tanaman srikaya menghasilkan jumlah daun terbanyak dan tunas tertinggi dibandingkan dengan konsentrasi $0,50,150$, dan 200 ppm. Berdasarkan penelitian Wulandari dkk. (2013), konsentrasi IBA 75 ppm menunjukkan hasil terbaik pada peningkatan jumlah akar dan jumlah rerata bobot basah akar dan bobot kering akar pada pertumbuhan stek melati putih (Jasminum sambac (L) W. Ait.). Hal ini dipicu oleh peningkatan aktifitas auksin endogen dalam memacu perpanjangan sel, sehingga dapat mempercepat pembentukan akar tanaman.

Dalam melakukan pembibitan manggis, diperlukan teknik penyemaian yang baik untuk menghasilkan bibit manggis yang bermutu tinggi. Penyemaian adalah kegiatan menumbuhkan benih menjadi bibit sebelum dipindah ke tempat penanaman. Teknik penyemaian yang biasa dilakukan adalah dengan cara membuat bedengan dalam sebuah naungan dengan media tanam yang berbeda antara bedengan penyemaian dan media pembibitan. Pemindahan tanaman yang berasal dari media penyemaian ke media tanam disebut pindah tanam. Pindah tanam harus dilakukan dengan hati-hati agar tidak merusak akar tanaman. Umumnya pemindahan tanaman dilakukan saat bibit berumur 5 - 6 minggu agar pertumbuhannya lebih optimal.

Berdasarkan uraian di atas perlu adanya pengkajian pemberian IBA dalam upaya mempercepat pertumbuhan akar pada bibit manggis asal biji. Namun, konsentrasi yang tepat belum diketahui. Selain itu, dimungkinkan untuk memperoleh benih manggis dalam jumlah banyak dan berkualitas dalam waktu yang relatif singkat, yaitu dengan cara pembibitan asal biji dengan mengombinasikan teknik penyemaian dengan penggunaan zat pengatur tumbuh IBA.

Penelitian ini bertujuan untuk mengetahui : (1) konsentrasi IBA yang menghasilkan pertumbuhan terbaik bibit tanaman manggis, (2) pengaruh teknik penyemaian terhadap pertumbuhan bibit tanaman manggis, dan (3) interaksi antara perbedaan konsentrasi IBA dan teknik penyemaian dalam mempengaruhi pertumbuhan bibit tanaman manggis.

\section{BAHAN DAN METODE}

Penelitian ini dilakukan di rumah kaca gedung Hortikultura Universitas Lampung pada Januari - Mei 2016. Bahan yang digunakan pada penelitian ini adalah biji manggis, larutan disinfektan dengan bahan aktif $\mathrm{NaOCl} 5,25 \%$, zat pengatur tumbuh IBA, KOH $1 \mathrm{~N}$, HCL $1 \mathrm{~N}$, fungisida dengan bahan aktif Mankozeb $80 \%$, tanah, kompos, sekam bakar, dan aquades. Alat - alat yang digunakan antaralain polybag, gembor, gelas ukur, labu ukur, tissue, pisau atau cutter, kamera, timbangan analitik, spatula, penggaris, jangka sorong, dan alat tulis.

Penelitian ini menggunakan rancangan acak kelompok (RAK) dengan perlakuan faktorial yang terdiri dari dua faktor $(4 \times 2)$. Faktor pertama: taraf konsentrasi IBA (A) yang terdiri: 0 ppm ( $\left.a_{0}\right), 25 \mathrm{ppm}\left(\mathrm{a}_{1}\right), 50 \mathrm{ppm}$ $\left(a_{2}\right)$, dan 75 ppm $\left(a_{3}\right)$. Faktor kedua: teknik penyemaian (B) tanam langsung $\left(b_{1}\right)$ dan pindah tanam $\left(b_{2}\right)$. Kombinasi perlakuan ini terdiri dari 8 perlakuan yang diulang 3 kali, sehingga diperoleh 24 satuan percobaan, dan masing-masing perlakuan terdapat 4 polybag tanaman. Kesamaan ragam data diuji dengan uji Bartlett dan kemenambahan diuji dengan uji Tukey. Data yang diperoleh diolah dengan analisis ragam dan dilanjutkan dengan perbandingan polynomial kontras dan polybomial orthogonal pada taraf á $5 \%$.

Penelitian ini dilaksanakan melalui beberapa tahapan, yaitu: persiapan media tanam, persiapan bahan tanam, penyemaian benih, pemberian zat pengatur tumbuh, dan pemeliharaan. Penanaman benih manggis dilakukan pada media tanah, kompos, dan sekam bakar dengan perbandingan 3:2:1. Pada tanam langsung, benih manggis ditanam di polybag ukuran $30 \mathrm{~cm} \times 15 \mathrm{~cm}$ dengan volume $2 \mathrm{~kg}$ dan penanaman pada pindah tanam dilakukan pada bak persemaian ukuran $85 \mathrm{~cm}$ x $85 \mathrm{~cm}$ yang kemudian pada umur 6 mst dipindah ke dalam polybag pada umur 6 mst. Pemberian IBA dilakukan tiga kali dengan cara penyiraman pada bagian akar tanaman sebanyak $10 \mathrm{ml} /$ tanaman dengan interval 10 hari sekali sesuai dengan konsentrasi masing-masing. Aplikasi dilakukan pada bibit manggis umur 6 mst. Variabel pengamatan yang dilakukan meliputi: tinggi tunas, jumlah daun, diameter batang, luas daun, panjang akar primer, jumlah akar sekunder, jumlah akar adventif, dan bobot seedling. 


\section{HASIL DAN PEMBAHASAN}

Hasil penelitian menunjukkan bahwa pemberian IBA $0-75 \mathrm{ppm}$ berpengaruh nyata terhadap diameter batang akhir pada pengamatan seedling namun tidak berpengaruh nyata pada variabel lainnya. Teknik penyemaian dan interksi antara keduanya juga tidak menunjukkan adanya pengaruh yang nyata pada semua variabel pengamatan (Tabel 1). Hal ini disebabkan oleh beberapa faktor, salah satunya adalah kebutuhan hormon yang berbeda setiap tanaman dalam memacu pertumbuhannya. Sesuai pendapat Wudianto (2005), bahwa zat pengatur tumbuh efektif dalam jumlah tertentu yang dapat berfungsi untuk mendukung, menghambat, dan mengubah proses fisiologi tumbuhan. Hal ini sejalan dengan penelitian Sudarmi (2008), yang menyebutkan bahwa konsentrasi IBA $100 \mathrm{ppm}$ berkorelasi positif dan menunjukkan pertumbuhan yang terbaik pada waktu kemunculan tunas, panjang tunas, panjang akar, jumlah daun, luas daun, dan bobot brangkasan segar stek tanaman jarak pagar (Jatropha curcas L.) dibandingkan konsentrasi $50 \mathrm{ppm}$ dan $150 \mathrm{ppm}$.

Pada pengamatan pertumbuhan seedling manggis, perlakuan IBA memberikan pengaruh yang nyata pada variabel diameter batang akhir dengan pola linier negatif (Gambar 1). Pengaruh tersebut negatif, artinya semakin tinggi pemberian konsentrasi IBA maka diameter batang akhir yang dihasilkan semakin kecil. Menurut Anisha (2015), pemberian IBA 0-300 ppm dengan cara perendaman pada biji hanya merangsang pembentukan dan pembesaran akar radikel saja, namun pembentukan tunas dan akar sejati terhambat sehingga pertumbuhan bibit kurang optimal.
Hasil penelitian ini menunjukkan bahwa pemberian IBA 0-75 ppm tidak menunjukkan respons yang nyata terhadapat panjang akar primer dan jumlah akar sekunder. Hal ini diduga karena pemberian konsentrasi IBA pada penelitian ini masih terbilang rendah. Pernyataan ini diperkuat oleh penelitian Kusdianto (2012), bahwa pemberian IBA konsentrasi $150 \mathrm{ppm}$ dengan perendaman selama 24 jam memberikan hasil pertumbuhan terbaik pada peningkatan jumlah akar, panjang akar, bobot segar, dan bobot kering akar dibandingkan dengan pemberian IBA $0 \mathrm{ppm}, 50 \mathrm{ppm}$, dan 100 ppm pada stek tanaman jeruk nipis (Citrus aurantifolia swingle). Selanjutnya, penelitian Karo (2014), menyatakan bahwa peningkatan jumlah daun tunas pada stek tanaman gambir (Uncaria gmbri Roxb) disebabkan oleh pemberian zat pengatur tumbuh IBA 150 ppm yang mempercepat pembentukan akar.

Teknik penyemaian tidak berpengaruh nyata pada pertumbuhan seedling manggis, namun hasil keseluruhan menunjukkan bahwa teknik penyemaian tanam langsung lebih baik dibandingkan pindah tanam. Hal ini dapat dilihat pada variabel bobot seedling dimana rata-rata yang dihasilkan untuk teknik tanam langsung adalah 2,56 gram dan teknik pindah tanam 2,31 gram. Hasil pengamatan ini diasumsikan bahwa bibit tanaman manggis dengan teknik pindah tanam mengalami kerusakan pada akar yang mengakibatkan tanaman sulit untuk tumbuh optimal.

Berdasarkan hasil penelitian yang telah dilakukan, bibit manggis yang telah dipindah tanam ke dalam polybag maupun yang ditanan langsung dalam polybag, ada yang mengalami kematian. Kematian bibit manggis ini mulai terlihat dari warna daun yang

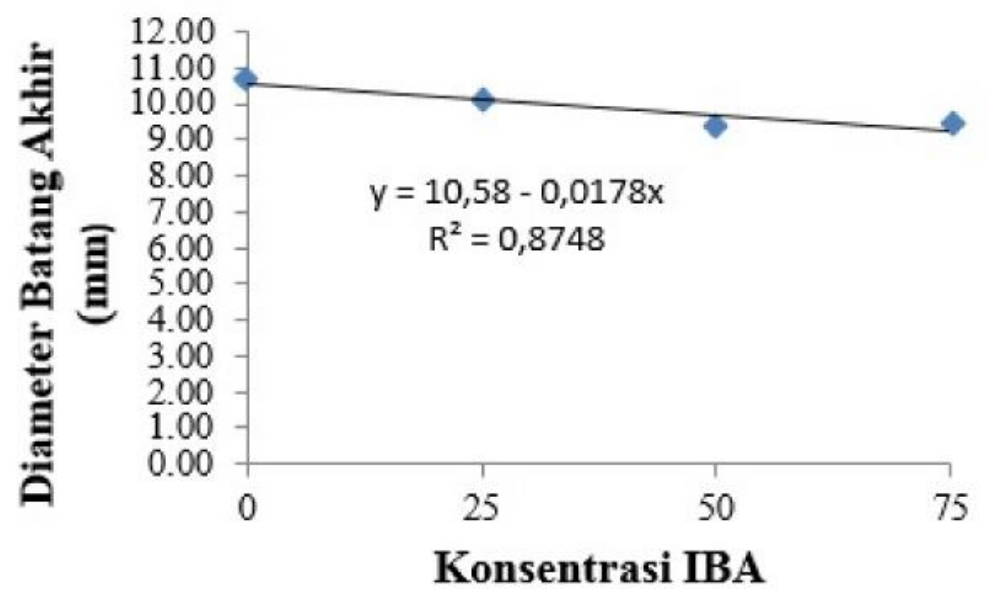

Gambar 1. Pengaruh konsentrasi IBA pada diameter batang akhir seedling tanaman manggis 18 minggu 
Tabel 1. Rekapitulasi hasil analisis ragam untuk pengaruh konsentrasi IBA dan teknik penyemaian pada pertumbuhan seedling manggis umur 18 minggu setelah tanam

\begin{tabular}{|c|c|c|c|c|}
\hline \multirow[b]{2}{*}{ Variabel } & \multicolumn{3}{|c|}{ Perlakuan } & \multirow[b]{2}{*}{ Kelompok } \\
\hline & IBA & $\begin{array}{c}\text { Teknik } \\
\text { Penyemaian }\end{array}$ & Interaksi & \\
\hline Tinggi Tunas (12 MST) & tn & tn & tn & tn \\
\hline $\begin{array}{l}\text { Tinggi Tunas (18 } \\
\text { MST) }\end{array}$ & tn & tn & tn & $*$ \\
\hline $\begin{array}{l}\text { Jumlah Daun (18 } \\
\text { MST) }\end{array}$ & tn & tn & tn & tn \\
\hline Luas Daun & $\operatorname{tn}$ & tn & tn & tn \\
\hline Diameter Batang Akhir & $*$ & tn & tn & tn \\
\hline Bobot Seedling & $\operatorname{tn}$ & tn & tn & $*$ \\
\hline Panjang Akar Primer & $\operatorname{tn}$ & tn & tn & tn \\
\hline Jumlah Akar Sekunder & tn & tn & tn & tn \\
\hline Jumlah Akar Adventif & tn & tn & tn & * \\
\hline
\end{tabular}

Keterangan : $\quad$ tn $=$ tidak berbeda nyata pada taraf $5 \%, *=$ berbeda nyata pada taraf $5 \%$

Tabel 2. Pengaruh pemberian aplikasi IBA dan teknik penyemaian terhadap kelompok bobot seedling pada pengamatan pertumbuhan seedling manggis umur 18 minggu setelah tanam.

\begin{tabular}{lll}
\hline \multicolumn{1}{c}{ Perlakuan } & Grade \\
\hline$>1,3$ gram & 2,72 & $\mathrm{a}$ \\
$1,1-1,3$ gram & 2,43 & $\mathrm{~b}$ \\
$<1,1$ gram & 2,15 & $\mathrm{c}$ \\
\hline
\end{tabular}

Keterangan:Angka yang diikuti huruf yang sama tidak berbeda menurut uji BNT 5\% 0,07.

kecoklatan dari bagian ujung daun kemudian menyebar ke seluruh bagian tanaman dan akhirnya tanaman tersebut mati. Gejala ini ditemukan setelah bibit berumur \pm 6 minggu setelah tanam. Persentase tanaman yang mengalami gejala ini mencapai $14,11 \%$ pada usia tanaman 18 minggu setelah tanam.

Rendahnya daya pertumbuhan manggis diakibatkan oleh beberapa sebab, antara lain: pemindahan tanaman dari media semai ke dalam polybag. Hal ini menyebabkan bibit menjadi stres karena kemungkinan sebagian akar mengalami kerusakan dan posisi akar berubah dari posisi semula pada media tanam awal. Akar tanaman manggis merupakan akar tunggang yang dalam namun miskin percabangan dan bulu akar (Nakasone dan Paull, 2010). Oleh karena itu perakarannya lemah yang apabila terkena gangguan sedikit akan berakibat pada terhambatnya pertumbuhan dan bahkan akhirnya mati.

Selain itu, pengaruh lingkungan juga berperan aktif dalam mempengaruhi pertumbuhan tanaman. Menurut Prihatman (2000), tanaman manggis membutuhkan temperatur udara yang ideal pada kisaran $22-32^{\circ} \mathrm{C}$. Penelitian ini dilakukan pada musim kemarau, sehingga suhu rumah kaca bisa mencapai $\pm 39^{\circ} \mathrm{C}$ yang 
menyebabkan tanaman mudah mengering. Kondisi ini berpengaruh terhadap bibit manggis dikarenakan transpirasi yang terjadi pada suhu tinggi berjalan lebih cepat. Ditegaskan oleh Lakitan (2012), bahwa proses transpirasi akan berjalan lebih cepat pada saat suhu tinggi dikarenakan peningkatan aktifitas buka-tutup stomata yang mengakibatkan peningkatan daya hantar stomata tersebut.

Pada penelitian ini, pengelompokkan berdasarkan bobot biji memberikan pengaruh yang nyata pada variabel tinggi tunas umur $18 \mathrm{mst}$, bobot seedling, dan jumlah akar adventif (Tabel 1). Kelompok bobot biji besar ( >1,3 gram) memiliki hasil lebih baik dibandingkan dengan kelompok bobot biji sedang (antara 1,1 - 1,3 gram ), dan kecil ( $<1,1$ gram ) yang dapat dilihat pada Tabel 2. Hal ini disebabkan kelompok biji besar memiliki cadangan makanan lebih banyak dibandingkan bobot biji lainnya sehingga memiliki pertumbuhan yang lebih optimal. Menurut Ashari (1995), fungsi cadangan makanan dalam biji adalah memberi makan kepada embrio maupun tanaman yang masih muda sebelum tanaman tersebut mampu memproduksi makanan sendiri.

\section{KESIMPULAN}

Berdasarkan hasil penelitian yang diperoleh, dapat disimpulkan bahwa: (1) pemberian IBA konsentrasi 0$75 \mathrm{ppm}$ pada pertumbuhan bibit manggis tidak berpengaruh pada semua variabel pengamatan, tetapi pada variabel diameter batang akhir justru menurunkan, (2) teknik penyemaian tidak berpengaruh nyata pada pertumbuhan bibit manggis, namun hasil keseluruhan menunjukkan bahwa teknik penyemaian tanam langsung berpotensi memiliki pertumbuhan lebih baik dibandingkan pindah tanam dilihat dari meningkatnya bobot bibit dan jumlah akar adventif pada tanam langsung, dan (3) pemberian IBA konsentrasi (0 ppm, $25 \mathrm{ppm}, 50 \mathrm{ppm}$, dan 75 ppm) dan teknik penyemaian tidak menunjukkan adanya interaksi terhadap semua variabel pengamatan.

\section{DAFTAR PUSTAKA}

Anisha. 2015. Pengaruh konsentrasi Indole-3-Butyric Acid (IBA) dan pembelahan biji terhadap perkecambahan dan pertumbuhan seedling manggis (Garcinia mangostana L.). (Skripsi). Universitas Lampung. Bandar Lampung. $124 \mathrm{hlm}$.

Ashari, S. 1995. Hortikultura: Aspek Budidaya. Universitas Indonesia Press. Jakarta. 485 hlm.
Budianto, E., A. K. Badami, dan A. Arsyadmunir. 2013. Pengaruh kombinasi macam ZPT dengan lama perendaman yang berbeda terhadap keberhasilan pembibitan sirih merah (Piper crocatum Ruiz \& Pav) secara stek. Agrovigor Universitas Trunojoyo Madura. 6.(2). 103-111.

Departemen Pertanian. 2015. Nilai dan Volume Ekspor Hortikultura. http;//www.pertanian.

go.id. Diakses pada tanggal 26 Oktober 2016 pukul 13.00 WIB.

Fanani, A. 2014. Sukses Berkebun Manggis. Indoliterasi. Yogyakarta. $86 \mathrm{hlm}$.

Karo, M. K. 2014. Pertumbuhan berbgai stek asal tanaman gambir (Uncaria gambir Roxb) akibat pemberian berbagai konsentrasi IBA. Jurnal Penelitian Lumbung. 13(2): 134-141.

Kusdianto, W. B. 2012. Efektifitas konsentrasi IBA (Indole Butyric Acid) dan lama perendaman terhadap pertumbuhan stek jeruk nipis (Citrus aurntifolia swingle). (Skripsi). Universitas Sebelas Maret. Surakarta. $53 \mathrm{hlm}$.

Lakitan, B. 2012. Dasar-Dasar Fisiologi Tumbuhan. Rajawali Pers. Jakarta. 205 hlm.

Nakasone, H. Y dan R. E. Paull. 2010. Tropical Fruits. CAB Internasional. New York. 400 p.

Prihatman, K. 2000. Manggis (Garcinia mangostana L.). Kantor Deputi Menegristek Bidang Pendayagunaan dan Pemasyarakatan Ilmu Pengetahuan dan Teknologi BPP Teknologi. Jakarta. 15 hlm.

Salim, H., N. E. F. Myrna, dan Y. Alia. 2010. Pertumbuhan bibit manggis asal seedling (Garcinia mangostana L.) pada berbagai konsentrasi IBA. Jurnal Penelitian Jurusan Agronomi Universitas Jambi. 12(2): 19-24.

Shofiana, A., Y. S. Rahayu, dan L. S. Budipramana. 2013. Pengaruh pemberian berbagai konsentrasi hormon IBA (Indole Butyric Acid) terhadap pertumbuhan akar pada stek batang tanaman buah naga (Hylocereus undatus). Jurnal LenteraBio. 2(1): 101-105. 
Sudarmi. 2008. Kajian Konsentrasi IBA terhadap Pertumbuhan Stek Jarak Pagar (Jatropha curcas L.). Majalah Pengetahuan dan Media Pendidikan. Univet Bantara. 33(3).

Sunarjono, H. 2000. Prospek Berkebun Buah. Penebar Swadaya. Jakarta. $127 \mathrm{hlm}$.

Wudianto, R. 2005. Membuat Setek, Cangkok dan Okulasi. Penebar Swadaya, Jakarta. $172 \mathrm{hlm}$.

Wulandari, R. C., R. Linda, dan Mukarlina. 2013. Pertumbuhan stek melati putih (Jasminum $\operatorname{sambac}(L) W$. Ait.) dengan pemberian air kelapa dan IBA (Indole Butyric Acid). Jurnal Protobiont. 2(2): 39-43.

Yulianto, A. G., E. Setiawan, dan K. Badami. 2015. Efek pemberian IBA terhadap pertautan sambung samping tanaman srikaya. Jurnal Agrovigor. 8(2): 51-56. 